\title{
Alergeny ziół kulinarnych i warzyw ważne dla pielęgniarki lub dietetyczki
}

\section{Allergens of the culinary herbs and vegetable important for nurse or dietitian}

KRZYSZTOF BUCZYŁKOํำ

${ }^{1}$ Instytut Nauk o Zdrowiu Państwowa Uczelnia Zawodowa we Włocławku

DOI: http://dx.doi.org/10.21784/IwP.2020.017

ISSN: 2451-1846

\section{Streszczenie:}

Wstęp. W pracy opisano nowe źródła alergenowe powodujące ustny zespół uczuleniowy oraz inne choroby alergiczne.

Przegląd. Zidentyfikowano i przedstawiono cząsteczki alergenowe przypraw, warzyw i niektórych ziół kulinarnych oraz ich możliwości reagowania krzyżowego. Niektóre z opisanych molekuł w zasadzie nie stanowią ryzyka ciężkich reakcji, co wykazano w odróżnieniu od komponent wywołujących reakcje uogólnione.

Podsumowanie. Podstawowe zasady alergologii molekularnej są przydatne zarówno dla pielęgniarek jak dietetyczek.

Słowa kluczowe: alergeny, zioła, pielęgniarka, dietetyczka. 


\begin{abstract}
:
Introduction. New allergenic sources causing the oral allergy syndrome and other allergic diseases have been reported.

Overview. The spices, vegetables and some culinary herbs allergenic molecules have been identified and presented with their cross-reactivity possibilities. Some of the molecules generally considered not to be at risk for severe reactions have been demonstrated to pose a threat for inducing generalized reactions.
\end{abstract}

Conclusions. Molecular allergology basic rules are useful for nurses and dietitians as well.

Keywords: allergens, herbs, nurse, dietitian.

Motto: Przyprawy sq szeroko stosowane i zawierają wiele alergenów, lecz alergie na zioła kulinarne pozostaja w znacznym stopniu nierozpoznane [1].

\title{
Wstęp
}

Nawyki żywieniowe człowieka zdrowego są efektem uwarunkowań społecznych, religijnych, ekonomicznych, kulturowych oraz upodobań osobistych, często związanych z genami. Wspomniane uwarunkowania powodują oczywisty fakt znacznego zróżnicowania osobistej listy ulubionych potraw [2]. Tymczasem w Internecie i innych mediach społecznościowych pojawiają się modne propozycje tzw. „zdrowego żywienia", zazwyczaj bazujące na jednym - rzekomo nowoczesnym i znakomitym - aspekcie tytułowym. Mamy więc diety bezglutenowe, dietę MIND (najlepszą dla mózgu), dietę przeciwzapalną itd. Pomijając chwilowo ich analizę medyczną warto zauważyć, że są one zazwyczaj apodyktycznie jednolite dla wszystkich czytających owe zalecenia lub bywają oparte na nieuznawanych przez Polskie Towarzystwo Alergologiczne metodach diagnostycznych.

W obecnej dobie szerokiego dostępu do informacji on line zapoznają się z tymi informacjami także chorzy, w tym uczuleni na alergeny 
pokarmowe. Dyplomowana pielęgniarka i dietetyczka powinny być świadome istnienia „alternatywnych dla wiedzy opartej na faktach” przekonań sporej części pacjentów.

W codziennym pożywieniu, a także w diecie pacjentów, stosuje się często świeże lub suszone zioła kulinarne, takie jak ziarna anyżu, gorczycy, kminku, jałowca, majeranku; liście szałwii, lubczyku, bazylii oraz części warzyw: cebuli, selera, marchwi, pietruszki itd. [3]. Niemal każdy słyszał o ich walorach zdrowotnych, a z pewnością wszyscy poznali ich wspaniałe zapachy i pikantne smaki. Jednak w mądrych książkach zielarskich i kucharskich znajdziemy także ostrzeżenia, że niektórym ludziom zioła, w tym przyprawowe, mogą mocno zaszkodzić [4].

\section{Cele pracy}

1.Czy spożyte po raz pierwszy pokarmy mogą zwierać molekuły alergiczne i skutkować anafilaksją? 2. Czy niektóre molekuły, niedawno wykryte w poszczególnych źródłach, np. ziołach kulinarnych takich jak anyż czy bazylia mogą być odpowiednikami znanych komponent silnie uczulających? 3. Czy obecnie znamy wszystkie alergeny ziół kulinarnych i warzyw dostępnych w Polsce? 4. Czy w alergii pokarmowej biorą udział mechanizmy immunologiczne typu IV? 5. Czy nietolerancja histaminy z niedoboru DAO występuje często? 6. Czy podstawowe zasady alergologii molekularnej są przydatne dla pielęgniarek i dietetyczek?

\section{Przegląd}

\section{Etiopatogeneza alergii pokarmowych na zioła i warzywa}

Najczęściej objawy alergii pokarmowej na zioła kuchenne i warzywa rozwijają się w przebiegu reakcji typu I wg Gella i Coombs'a, z udziałem swoistych przeciwciał E (sIgE). Przywołana klasyfikacja rzadziej obejmuje $\mathrm{w}$ odniesieniu do pokarmów i ich chemicznych składników także reakcje typu IV W około $1 / 3$ przypadków 
mechanizmy te nakładają się i mówimy o postaciach mieszanych, częstych w atopowym zapaleniu skóry u dzieci [5]. Nieimmunologiczne rodzaje nietolerancji pokarmowej dotyczą około 15-20\%, natomiast klasyczne (immunologiczne) postacie alergii pokarmowej 2 - 2,5\% populacji [6]. Do innych mechanizmów, wywołujących podobne do zapalenia alergicznego skutki kliniczne pseudoalergiczne, zaliczamy niedobory enzymów na przykład histaminazy (DAO) czy laktazy [7]. W pewnej grupie osób z niedoborem diaminooksydazy (DAO), niezależnie od ewentualnej alergii, szkodzić mogą przetwory, na przykład kiszona kapusta bogata w histaminę czy dojrzewające wędliny i sery [5]. Nietolerancja histaminy jest stanem klinicznym, który opisuje niezdolność niektórych osób do degradacji histaminy i powoduje początek objawów spowodowanych jej gromadzeniem się we krwi [7]. Wspomniana typologia nie jest jednak rozłączna. Pojawiają się kolejne prace o współistnieniu u jednego pacjenta różnych reakcji immunologicznych lub/i nieimmunologicznych, a literatura tematu stopniowo się powiększa [8, $9,10]$. Lepsze zrozumienie alergii na zioła kulinarne i warzywa zacznijmy od zarysu etiopatogenezy mechanizmów IgE-zależnych (humoralnych) [11].

\section{Reakcje IgE- zależne wobec ziół przyprawowych i warzyw}

Kontakt alergenu z przeciwciałem E (IgE) powoduje zazwyczaj reakcje szybkie, do około 2 godzin po spożyciu, niekiedy gwałtowne (anafilaktyczne). Mówimy wówczas o reakcji humoralnej typu I wg Gella i Coombsa [12]. Przymiotnik humoralne podkreśla fakt, że przeciwciała E są zawarte w surowicy, choć mogą wiązać się z komórkami poprzez odpowiednie receptory (chwytniki). Jako przyczynę podobnych alergii pokarmowych uważano do niedawna „oddzielne” pokarmy- seler albo bazylię itd, a ich szkodliwość badano za pomocą punktowych testów skórnych (PTS) lub oznaczeń IgE dla wyciągu (ekstraktu) danego pokarmu. Obecnie, oprócz takich „oddzielnych” oznaczeń IgE, dla 
całej, zawartej choćby w selerze mieszaniny wielu białek, możemy wykryć poszczególne składniki inaczej zwane komponentami albo molekułami faktycznie uczulającymi. Pacjent w gabinecie alergologa dowiaduje się często o swoim uczuleniu na pyłek brzozy, głównie związany z molekułą Bet v 1- od Betula verrucosa - brzoza brodawkowata, albo na kota - np. cząsteczkę albuminy Fel d 2 - od Felis domesticus - kot domowy [2]. Przyjmuje on ten fakt do wiadomości tym łatwiej, im się tego po okolicznościach występowania swoich dolegliwościach spodziewał. Jednak następna opinia pielęgniarki wykonującej testy alergiczne czy lekarza planującego dalsze postępowania, jest traktowana z dużym niedowierzaniem. Brzmi bowiem: pan/pani ma prawdopodobnie także alergię pokarmową na surowe owoce, orzechy, warzywa i zioła w przypadku zależnym od Bet $\mathrm{v} 1$ brzozy lub alergię na surowe mięso wieprzowe ( $w$ tym wędliny) w przypadku zależnym od Fel d 2 kota. Prawidłowym wyjściem z takiej różnicy zdań, gdy chory zazwyczaj twierdzi, że „wszystko może jeść, a ta wysypka to na pewno z nerwów", jest wykonanie naturalnych testów ze świeżych produktów oraz kontrolowane próby prowokacji pokarmowej. Warto przypomnieć, że wywołane pokarmem alergie powodują liczne objawy skórne, jelitowe i oddechowe. Wynika z tego pięć kluczowych dla pielęgniarki i dietetyczki kwestii.

Po pierwsze-przykładowo u pacjenta A.B. lat 17 (dane zmienione zgodnie z RODO) z katarem wiosennym, uczulenie (wysokie miano IgE) dotyczyło tylko białek roślinnych z 10-tej grupy związanej z chorobowością (pathogenesis related, PR-10), konkretnie głównego białka pyłku brzozy Bet v 1. Oznacza to wysokie ryzyko reakcji pokarmowej po spożyciu świeżych pokarmów zawierających PR-10. Ich przykłady zawiera tabela 1. 
Tab. 1. Alergeny IgE zależne ziół kulinarnych i warzyw [opracowanie Krzysztof Buczyłko w oparciu o 2,13, 17,19,26].

\begin{tabular}{|c|c|c|c|}
\hline Zioła kulinarne & Warzywa & $\begin{array}{c}\text { Komponenta } \\
\text { (molekuła) } \\
\text { alergiczna }\end{array}$ & Pyłek roślin \\
\hline $\begin{array}{l}\text { Cor s } 1 \text { kolendra, } \\
\text { Cum c } 1 \text { kumin, } \\
\text { Pim a } 1 \text { anyż, } \\
\text { Car c kminek }\end{array}$ & $\begin{array}{l}\text { Api g } 1 \text { seler, } \\
\text { Dau c } 1 \text { marchew, } \\
\text { Foe v } 1 \text { koper włoski, } \\
\text { Pet c } 1 \text { pietruszka, } \\
\text { Sola l } 4 \text { pomidor }\end{array}$ & $\begin{array}{l}\text { Bet v like PR-10 } \\
\text { (białko związane } \\
\text { z patogenezą) }\end{array}$ & $\begin{array}{l}\text { Bet v } 1 \\
\text { brzoza, } \\
\text { Aln g } 1 \text { jesion }\end{array}$ \\
\hline $\begin{array}{l}\text { Cor s } 2 \text { kolendra, } \\
\text { Cum c } 2 \text { kumin, } \\
\text { Pim a } 2 \text { anyż, } \\
\text { Cro s szafran, } \\
\text { Car c kminek }\end{array}$ & $\begin{array}{l}\text { All c } 4 \text { cebula, } \\
\text { Api g } 4 \text { seler, } \\
\text { Cap a } 2 \text { papryka, } \\
\text { Dau c } 4 \text { marchew, } \\
\text { Foe v } 2 \text { koper włoski, } \\
\text { Pet c } 2 \text { pietruszka, } \\
\text { Sola } 11 \text { pomidor }\end{array}$ & $\begin{array}{l}\text { Profilina } \\
\text { (białko wiążące } \\
\text { aktynę) }\end{array}$ & $\begin{array}{l}\text { Bet v } 2 \\
\text { brzoza, } \\
\text { Phl p } 12 \\
\text { tymotka }\end{array}$ \\
\hline Sin a 3 gorczyca & $\begin{array}{l}\text { All c } 3 \text { cebula, } \\
\text { Api g } 2 \text { selera, } \\
\text { Bra a } 3 \text { kalafior, } \\
\text { Bra o } 3 \text { kabaczek } \\
\text { Dau c } 3 \text { marchew, } \\
\text { Pet c } 3 \text { pietruszka, } \\
\text { Pis s } 3 \text { groch, }\end{array}$ & $\begin{array}{l}\text { nsLTP PR } 14 \\
\text { (białko transpor- } \\
\text { tujące niespecy- } \\
\text { ficzne lipidy) }\end{array}$ & $\begin{array}{l}\text { Amb a } 3 \\
\text { ambrozja, } \\
\text { Art v } 3 \text { bylica, } \\
\text { Par j pomur- } \\
\text { nik }\end{array}$ \\
\hline $\begin{array}{l}\text { Oci b TLP1 } \\
\text { bazylia }\end{array}$ & $\begin{array}{l}\text { Cap a } 1 \text { papryka } \\
\text { Lac s TLP sałata, } \\
\text { Bra r TLP kapusta } \\
\text { Sol t TLP ziemniak }\end{array}$ & $\begin{array}{l}\text { TLP PR5 } \\
\text { (białko podobne } \\
\text { do taumatyny) }\end{array}$ & $\begin{array}{l}\text { Jun a } 3 \text { cedr } \\
\text { japoński, } \\
\text { Pla m a TLP } \\
\text { platan }\end{array}$ \\
\hline $\begin{array}{l}\text { Car c eEF1a } \\
\text { kminek }\end{array}$ & Dau c IFR marchew & $\begin{array}{l}\text { Inne znane } \\
\text { molekuły }\end{array}$ & Wiele roślin \\
\hline $\begin{array}{l}\text { Oci b bazylia, Lev } \\
\text { o lubczyk } \\
\text { Ori v oregano }\end{array}$ & $\begin{array}{l}\text { Pas s pasternak } \\
\text { Inne? }\end{array}$ & $\begin{array}{l}\text { Niepoznane mo- } \\
\text { lekuły alergiczne }\end{array}$ & Wiele roślin \\
\hline
\end{tabular}

Odcieniem szarym wyróżniono molekuły termostabilne, niosące ryzyko anafilaksji. 
Druga ważna w praktyce pielęgniarskiej wiadomość brzmi bardziej optymistycznie: ten chory będzie miał miejscowe symptomy obrzęku małżowin nosowych, warg, języka, nawet gardła (kula alergiczna gardła) czy tzw. ustno-gardłowego zespołu uczuleniowego (UZU, ang. OAS), [15] ale zazwyczaj nie dozna uogólnionych objawów wstrząsu anafilaktycznego i nie będzie wymagał natychmiastowej interwencji [16].

Trzecia nauka z oznaczenia IgE dla molekuły Bet v 1 zamiast oddzielnie dla mieszanin komponent jabłka, selera, marchwi, bazylii, brzozy czy leszczyny to informacja o właściwościach kulinarnych cząsteczki Bet v1 i jej odpowiedników (homologów) w pokarmach. Otóż białka z grupy PR-10, takie jak jabłkowe Mal d 1, selerowe Api g 1, marchwiowe Dau c 1, pietruszkowe Pet c 1 i bazyliowe Oci b są termolabilne [12]. Oznacza to, że poddane ogrzewaniu tracą właściwości wywoływania objawów uczulenia. Wystarczy więc w diecie naszego przykładowego pacjenta $\mathrm{AB}$ zalecić kompot zamiast świeżego soku lub zupę zamiast surówki i problem znika. To ważne, bo chociaż izolowany alergiczny nieżyt nosa wywołany pokarmem nie jest częsty, lecz towarzyszy innym objawom alergii pokarmowej jak astma, egzema, wspomniany UZU, pokrzywka, dolegliwości żołądkowo-jelitowe [11]. Alergia zależna od PR-10 (homologi Bet v 1) bywa reakcją jedynie na świeże zioła, które po obróbce termicznej tracą alergizujące właściwości. Lecz nie zawsze, gdyż alergię zależną od innej - termostabilnej i opornej na trawienie molekuły nsLTP - powodować mogą curry, pieprz kajeński czy zielony w potrawach smażonych czy pieczonych, nawet w wysokich temperaturach [5].

Po czwarte- niektóre osoby uczulone np. na pomidory potrafią wyszukać odmiany dla nich najmniej szkodliwe. Z punktu widzenia nauki zależy to od ilości ochronnych białek takich jak PR-10 w konkretnej partii owoców, przy czym wpływ ma na to kraj pochodzenia, sposób uprawy, właśnie odmiana [8] itp. Moi pacjenci z UZU na ogół wybierają 
duże, mięsiste pomidory (tzw. gargamele) i pilnie zdejmują z nich skórkę przed spożyciem. Niedawne badania ekologicznych i polnych odmian pomidorów ujawniły odmienny poziom molekuł alergenowych w poszczególnych odmianach, bez przewagi dla ekologicznych [17].

Po piąte- wiele badań wskazuje na skuteczność odczulania zarówno podskórnego jak i podjęzykowego roztworem pyłku brzozy na ustępowanie objawów pokarmowych (np. UZU) nawet po spożyciu świeżych pokarmów zawierających odpowiedniki PR-10 [13].

\section{Reakcje IgE-niezależne wobec ziół przyprawowych i warzyw}

Druga duża grupa ryzyka alergii pokarmowej kryje się w znacznie gorzej poznanej kategorii odpowiedzi pojawiających się klinicznie po kilku kilkunastu godzinach, albo nawet jak mawiają moi pacjenci ,już następnego dnia". Mechanizm patogenetyczny tych odpowiedzi jest związany z komórkami immunologicznie kompetentnymi i w klasyfikacji wg Gella i Coombsa należy do reakcji typu IV, inaczej reakcji opóźnionych [14].

Do czynników wyzwalających reakcje komórkowe typu opóźnionego zaliczamy substancje drobnocząsteczkowe (hapteny) oraz niektóre większe fragmenty dużych molekuł białkowych (epitopy) [6]. Podział ten $\mathrm{z}$ jednej strony budzi krytykę badaczy wątpiących w istotną rolę haptenów w pożywieniu, a z drugiej zastrzeżenia praktyków mniej doświadczonych w biochemii molekularnej epitopów w odniesieniu do reakcji typu IV. Dla przejrzystości niniejszego wywodu, ale także z racji przydatności w pracy z chorymi, autor uznaje ten podział za przydatny.

\section{Reakcje IgE niezależne z epitopami w ziołach kulinarnych i warzy- wach}

Poszukiwano głównego białka Bet v 1 który indukuje odpowiedź komórek $\mathrm{T}$ oraz krzyżową alergię pokarmową. Ustalono, że rolę tą pełni fragment (epitop) Bet v 1 142-156. Reaguje z nim 61\% komórek 
T. Reakcja występuje zarówno po podaniu molekuły pyłku brzozy jak i homologicznych pokarmów (jabłka- Mal d 1), wiśni (Pru av 1), orzecha laskowego (Cor a 1), selera (Api g 1) marchewki (Dau c 1) i soi (Gly m 4) [6]. W ten sposób znaleziono cząstkę odpowiedzialną zarówno za alergię wziewną jak i pokarmową oraz za reakcje wypryskowe, także poza sezonem pylenia. $W$ innej grupie pacjentów uczulonych na pyłki brzozy, którzy wykazywali najwyższy odsetek pozytywnych odpowiedzi SPT na jabłka Golden Delicious, a najniższy na mało alergizującą odmianę Grey French Reinette, u 9\% wystąpiły opóźnione reakcje nadwrażliwości na te jabłka. Reakcje te objawiły się klinicznie jako rumień z grudkami (klasa ++). Połowa pacjentów z APT (+) była jednocześnie ujemna pod względem SPT. Autorzy wykazali po raz pierwszy kliniczne znaczenie reakcji alergicznych na jabłka wywołanych przez limfocyty T. APT może ujawnić uczulenie typu IV u pacjentów, którzy mają negatywny wynik w odpowiednich testach uczulenia typu I [18]. Nie-alergologom wyjaśniam, że procedura atopowego testu płatkowego (ATP) wykorzystuje nietknięte (natywne, naturalne) alergeny białek (zawierających wspomniane epitopy) zamiast haptenów w zoptymalizowanym ustawieniu testu i ze specjalnym wzorcem odczytu. Może to być klinicznie przydatne, zwłaszcza w przypadku AZS, ponieważ obecnie dostępne procedury testowe albo celują w niewłaściwy typ reakcji (typ I, a nie typ IV) albo wykorzystują niewłaściwe alergeny (hapteny, a nie alergeny białkowe). Pozytywna reakcja ATP koreluje z dodatnim wynikiem testu transformacji limfocytów i swoistymi dla alergenu komórkami Th2 we krwi obwodowej [10].

Apiaceae jest rodziną roślin zielnych liczącą więcej niż 3000 gatunków występujących w miejscach o klimacie umiarkowanym, wykorzystywanych jako żywność (marchew, pasternak i seler) i jako przyprawy (pietruszka, kumin, koperek, koper włoski, majeranek, kminek, anyż i kolendra). Ta rodzina roślin jest związana $\mathrm{z}$ alergicznymi 
reakcjami nie tylko wywołującymi problemy oddechowe i alergie pokarmowe, ale także alergie kontaktowe [19].

APT może wykryć uczulenie na alergeny u pacjentów z AZS, nawet gdy wykazują ujemny punktowy test skórny i ujemny wynik testu IgE in vitro przeciwko mieszaninom alergenowym. W APT stosowano naturalną żywność lub roztwory do skórnych testów punktowych na bibule filtracyjnej i oczyszczone alergeny w wazelinie. Europejska grupa robocza ds. Atopowego zapalenia skóry (ETFAD) pracowała nad standaryzacją tego testu w kontekście pacjentów z AZS, którzy są uczuleni na alergeny wziewne i żywność. Ta znormalizowana technika obejmuje wykonanie testu w górnej części pleców z zastosowaniem dużych, 12milimetrowych komór Finn Chamber [9].

\section{Reakcje IgE niezależne z haptenami w ziołach kulinarnych i warzy- wach}

Alergeny kontaktowe są to związki chemiczne, w większość hapteny o niskiej masie cząsteczkowej do 500 daltonów. Związki te stają się pełnowartościowymi alergenami dopiero po związaniu się z białkami człowieka. Następuje pobudzenie (stymulacja) limfocytów Th1 przez komórki Langerhansa, wystawione na działanie związków, które nabrały cech antygenowych po kontakcie z białkami. Prowadzi to do rozwoju objawów chorobowych [20]. Rozpoznanie stawiamy na podstawie testów płatkowych (TP) z użyciem mniejszych (8 mm średnicy) komór Finn Chamber. Reakcje na hapteny w tym jony metali potwierdzamy za pomocą zestawów do testu płatkowego np. TRUE test [9], Europejska lub Polska Seria Podstawowa [14] itd. Ukryta alergia kontaktowa, bez widocznych oznak lub symptomów, może utrzymywać się przez całe życie [10]. Wśród dzieci w wieku 0 do 18 lat TP były kontaktowo uczulone najczęściej na nikiel $(26,0 \%)$, kobalt $(12,4 \%)$, neomycynę $(4,4 \%)$, mieszaninę zapachową $(4.1 \%)$, złoto $(3,6 \%)$ oraz 
kwaternium 15 (3,6\%). Dzieci z TP (+) w 34\% miały AZS zaś dorośli$11,2 \%[20]$.

Zdaniem Sharma AD i wsp. [21] nikiel (Ni) jest obecny w części produktów dietetycznych, a żywność jest uważana za główne źródło narażenia na nikiel drogą doustną w populacji ogólnej. W diecie osoby wrażliwej nikiel może wywołać zapalenie skóry [22]. Staranny dobór żywności może przynieść zmniejszenie całkowitego dziennego spożycia niklu oraz objawów alergii [21]. Niektórzy badacze, jak wspomniano, negują tą oczywistość. Pisze oczywistość, bo wśród moich licznych pacjentów ze zmianami kontaktowymi skóry, spojówek, błon śluzowych dieta niskoniklowa oparta o wynik TP wielokrotnie okazała się korzystna. Najczęściej nikiel uczulał w migdałach, ketchupie, orzechach, kakao, czekoladzie, zielonej i czarnej herbacie, chipsach [22].

Alergia na chrom (Cr) nie jest rzadkością, jej częstość występowania wynosi $6 \%$ oraz ma tendencję do utrzymywania długo. Zawartość Cr w żywności często różni się znacznie [23]. Uznane za źródła chromu pokarmy to: wątroba cielęca, groszek zielony (po 0,42 mg/kg), pomidory, sery, jaja (po $16 \mathrm{mg} / \mathrm{kg}$ ), pieczywo pełnoziarniste, halibut, cebula, kukurydza (po $20 \mathrm{mg} / \mathrm{kg}$ ) [3]. Niektórzy chorzy mogą bezkarnie zjeść pół jaja czy pomidora. Cr w diecie osoby wrażliwej może wywołać zapalenie skóry, gardła, spojówek i jelit. Staranny dobór żywności o stosunkowo niskiej zawartości może to wpływać korzystnie na stan choroby [23].

W praktyce własnej rzadziej występuje reakcja kontaktowa na balsam peruwiański (tożsamy z propolisem), obecny w kosmetykach, lekach stosowanych miejscowo, skórkach owoców cytrusowych, przyprawach, perfumowanej herbacie i tytoniu, olejkach eterycznych, gumie do żucia, lodach [3]. Alergeny kontaktowe w żywności to stosunkowo nowym problemem w systemach bezpieczeństwa zdrowotnego. Do większości ciast i ciasteczek można dodać przyprawy i substancje zapachowe, aby poprawić lub wzmocnić aromat i smak. Te przyprawy 
i zapachy nazywane są substancjami smakowymi. Do przypraw naturalnych zalicza się również przyprawy warzywne do produkcji żywności [24]. Ostatnio ustalono urzędowo, że w produktach kosmetycznych ani pokarmach nie należy stosować lyralu, atranolu i chloroatranolu, ponieważ są one alergenami zapachowymi, które były przyczyną największej liczby przypadków alergii kontaktowej w ostatnich latach [25]. Mniej oczywistymi źródłami limonenu są olejek nasion selera (do 75\%), olejek eukaliptusowy, szałwiowy, lawendowy oraz olejek kopru włoskiego (fenkułowy). Olejek miętowy zawiera rzadszy izomer L-limonen, którego zapach opisuje się jako sosnowy lub terpentynowy [14].

\section{Kilka przykładowych białek warzyw}

Warto zacząć od korekty wiedzy zastanej i bardzo rozpowszechnionej. Zapewne każda pielęgniarka zetknęła się z pojęciem „skazy białkowej”. Jednak określenie to, choć dokładnie odpowiada naturze alergii pokarmowych, jest zazwyczaj mylnie ograniczane do białek mleka i jaja. Tymczasem faktycznie uczulające białka, powodujące liczne przypadki owej „skazy” to proteiny marchwi lub bazylii albo innych warzyw i przypraw. Pokazuje tą złożoność np. pospolita pietruszka (Petroselinum crispum) lub cebula (Allium cepa). 


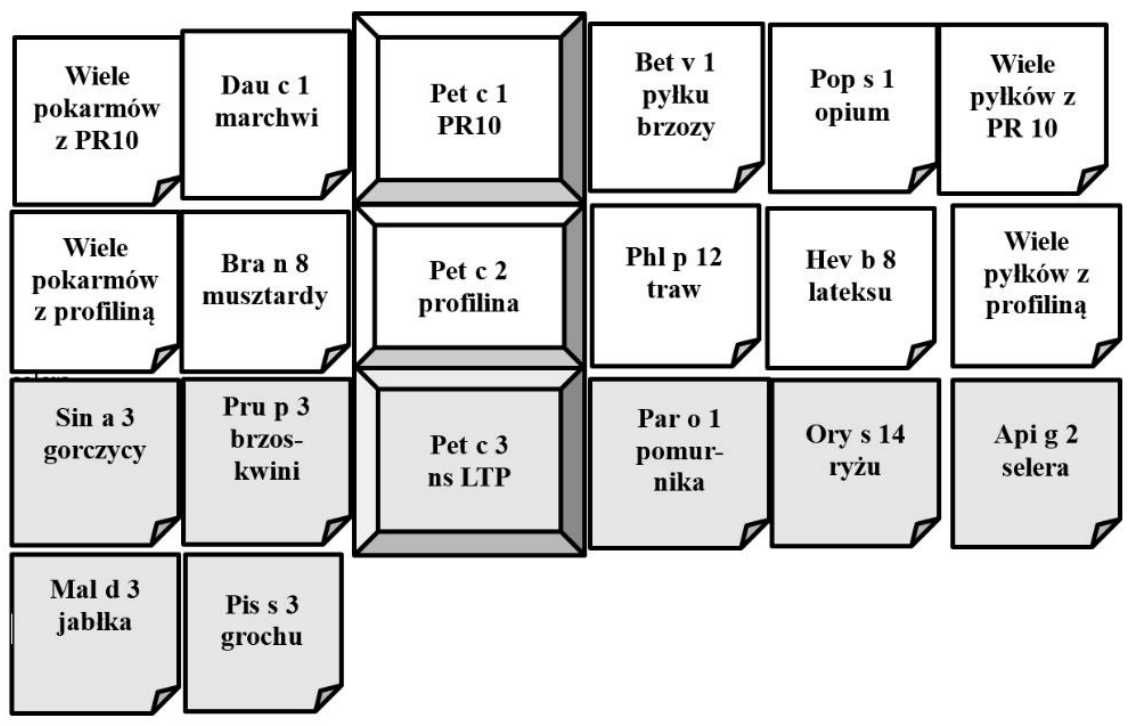

Ryc 1 . Teoretyczna orientacyjna tabela efektów molekularnych (totem) pietruszki.

Ekstrakt (wyciąg pietruszki) kod Pet c (dawniej f86) to naturalna mieszanina następujących składowych białek (molekuł): Pet c 1 grupa PR-10 (odpowiednik Bet v 1 brzozy, Mal d 1 jabłka, Dau c 1 marchwi, Pap s 1 opium, Dio k 1 owocu szaron - łącznie 220 roślin); Pet c 2 profilina (krzyżowo z Phl p 12 traw, Hev b 8 lateksu, Bra n 8 musztardy, Cor a 2 orzecha laskowego itd.) Pet c 3 nsLTP (krzyżowo ze 177 roślinami w tym Pru p 3 brzoskwini, Sin a 3 gorczycy, Pis s 3 grochu, Mal d 3 jabłka, Ory s 14 ryżu) itd. Opisano UZU od Pim a 1 (jednej z 97 znanych homologów Bet v1 z grupy PR-10) [13].

Cebula to powszechnie dostępne, tanie warzywo, które ze względu na wyrazisty smak stanowi nieodłączny dodatek do wielu dań. Ceniona jest także w medycynie naturalnej [3 Gawecki]. Mało kto jednak odróżnia 
jej białka alergiczne w tym homologi LTP (All c 3), białko All c 30 kD, profilinę (All c 4), liazę allinową. Liaza silnie reaguje krzyżowo z szalotką i porem oraz jest głównym alergenem, czosnku. Opisano sporadyczne przypadki anafilaksji na cebulę, prawdopodobnie z powodu uczulenia pacjenta na LTP [26].

\section{Wybrane przykłady alergicznych białek ziół przyprawowych}

Anyż -biedrzeniec anyż (Pimpinella anisum) ma wielorakie zastosowania w kuchni i medycynie [3] W jego składzie znaleziono alergeny Pim a 1(podobny do Bet v 1 brzozy) oraz Pim a 2 -homologiczny do wielu 9profilin [19] Kolendra siewna (koriander) Suszone owoce tej rośliny są niezastąpionym dodatkiem do ciast i wypieków świątecznych. Kolendra stanowi ważny składnik mieszanki curry. Przyprawia się nią dania mięsne [3]. Ekstrakt Cor s. Cor s 1 grupa PR-10, Cor s 11 kD czynność nieznana. Opisano anafilaksję po spożyciu Cor s, Cor s 2 profiliny [19]. Kminek (Carum carvi) Ekstrakt Car c. Kminek należy do rodziny baldaszkowatych (Apiaceae). Nasionka te poprawiają trawienie, mogą zapobiec wzdęciom i niestrawnościom [3]. Wykryto w nich alergeny homologiczne dla Bet v 1, profiliny i czynnika elongacji alfa podobnego do tegoż białka w lateksie [19].

Bazylia (Ocimum basilicum), f269, ekstrakt Oci b, brak danych o molekułach. Stosuje się ją najczęściej do potraw kuchni włoskiej. Surowice uczulonych reagują z LTP brzoskwini Pru p 3 oraz Bet v 1 pyłku brzozy [21]. Ze względu na zawartość olejków eterycznych o właściwościach mutagennych nie są zalecane kobietom w ciąży i matkom karmiącym piersią. Bazylii, nie zaleca się również podawania dzieciom poniżej 12 roku życia [3]. Pomiędzy bazylią a innymi roślinami z rodziny wargowych (Lamiaceae) takimi, jak: mięta, oregano, lawenda, majeranek, tymianek, szałwia może występować zjawisko alergii krzyżowej [12]. 
Właściwości alergizujące mieszanek przyprawowych określane są jako wysokie i wynikają z alergizującego działania poszczególnych składników. Najpopularniejsze w Polsce to curry i zioła prowansalskie. W skład curry wchodzą: kurkuma, kozieradka, gałka muszkatołowa, kolendra, pieprz czarny, goździki, czosnek, cynamon, kardamon, chili, kmin rzymski, imbir, sól, glutaminian sodu [16]. Po spożyciu curry odnotowano wstrząs anafilaktyczny [1]. Natomiast składnikami ziół prowansalskich są: rozmaryn, bazylia, tymianek, szałwia, mięta pieprzowa, estragon, cząber ogrodowy, lebiodka, majeranek [21].

\section{Objawy kliniczne alergii na zioła kulinarne i warzywa}

Zespół alergii jamy ustnej (OAS), zwany również „zespołem uczulenia na pyłki i pokarmy" lub PFAS (Pollen Food Allergy Syndrome), jest rodzajem alergii pokarmowej wywoływanej przez przyprawy, orzechy, surowe owoce i warzywa. Najbardziej znanymi objawami są swędzenie jamy ustnej i gardła, które pojawia się szybko po włożeniu pokarmu do ust i trwa z reguły tylko przez kilka minut do 2 godzin po połknięciu pokarmu. Częstość występowania OAS z alergią na pyłki wynosi 5-8\%; tylko 1-2\% pacjentów z OAS i alergią na pyłki wykazuje skrajne reakcje, w tym anafilaksję $\mathrm{i}$ jest to wówczas zależne od białek innych niż PR-10 [15]. Istnieją różne raporty dotyczące występowania PFAS, od 4,7\% do ponad $20 \%$ u dzieci i od 13\% do 58\% u dorosłych [16]. Częstość występowania różni się znacznie w zależności od regionu geograficznego. PFAS jest zwykle wynikiem alergenów pokarmowych klasy II (uczulenie pierwotne na alergen pyłkowy, ale reakcja występuje z powodu reaktywności krzyżowej alergenu pokarmowego). Zwykle te reakcje są ograniczone do jamy ustnej i gardła z powodu niestabilności białek powodujących reakcję. Ponieważ wiele rodzin białek o różnej stabilności powoduje PFAS, możliwe są również ciężkie reakcje ogólnoustrojowe. Wstrząs anafilaktyczny został udokumentowany w 1,7\% reakcji [4]. Wykrycie tych 2 ze stu osób wymaga właśnie diagnostyki 
molekularnej, po której pozostałe 98 badanych nie wpadnie we wstrząs po warzywach. Pacjenci z OAS wykazywali wyraźne reakcje na odmiany jabłek. Szara Reneta i Cortland wywołali pozytywne odpowiedzi odpowiednio u 50\% i 83\% pacjentów [8].

$\mathrm{U}$ dzieci pospolite kliniczne postacie alergii pokarmowych to wyprysk, kolka oraz refluks żołądkowo-przełykowy [4]. Potwierdzono w każdej z tych jednostek chorobowych obecność trzech typów alergii pokarmowych: IgE zależnej, mieszanej IgE/nie-IgE, oraz niezależnej od IgE. Według danych klinicznych i testów wszystkie 3 typy alergii pokarmowych można rozpoznać już we wczesnym dzieciństwie, aby wyjaśnić narastanie reakcji IgE niezależnych [6].

Alergeny pokarmowe mogą powodować u niektórych osób reakcję umiarkowaną do ciężkiej, zagrażającej życiu. Rzadko polega ona na izolowanej astmie bez innych objawów. Chora CD 1.24 w wywiadzie wstrząs anafilaktyczny po orzechach. Nawracające obrzęki powiek, gardła, ciężar w klatce piersiowej, pokrzywki. Pomiar FeNO 120 ppb (norma do 25 ppb). Nigdy wcześniej nie rozpoznano astmy. Wynik zaskoczył pacjentkę (obserwacje własne autora). U około $1 / 4$ chorych $\mathrm{z}$ astmą pyłkową epizody duszności wiążą się ze spożyciem surowej marchwi, które zawiera ten sam komponent PR10, co pyłek traw i bylicy [2].

Komponenty alergiczne chwastów, takich jak bylica, dają częste reakcje krzyżowe z ziołami, przyprawami i warzywami. Opisano przypadki astmy na rumianek i bylicę, seler i bylicę itp. [16]. NsLTP jest dobrze znaną alergologom termostabilną proteiną, o znacznym ryzyku wywoływania reakcji miejscowych i anafilaktycznych. Homologi Can s 3 występują w brzoskwini n Pru p3, mąkach (w tym pszennej Tri a 14), orzechach (w laskowych Cor a 8), piwie (Hum l LTP) lub winie (Vit v 1) oraz głównym alergenie pyłku bylicy Art v 3 [4]. 


\section{Podsumowanie}

1.Wiele nowych dla nas pokarmów zawiera „stare” czyli wcześniej znane molekuły alergenowe związane $\mathrm{z}$ reakcją immunologiczna zależną od IgE, co może skutkować anafilaksją już po pierwszym spożyciu. 2. Niektóre molekuły, dopiero co wykryte w poszczególnych źródłach, np. ziołach kulinarnych takich jak anyż czy bazylia okazują się być odpowiednikami znanych komponent uczulających, co może skutkować anafilaksją już po pierwszym spożyciu. 3. Wiele pokarmów, w tym także ziół przyprawowych nie ma określonego składu alergenów. Co nie oznacza, że są bezpieczne dla alergików, ponieważ reakcje krzyżowe pokarmowo-pokarmowe lub pyłkowo-pokarmowe są w Polsce powszechne. 4. Charakterystyczna dla reakcji immunologicznej typu IV alergia kontaktowo-pokarmowa na metale i hapteny zapachów pozostaje nadal mało znana, podobnie jak reakcje komórkowe na epitopy ziół kulinarnych i warzyw biorące udział w tej reakcji. 5. Nietolerancja histaminy z niedoboru DAO nie występuje często, może mieć jednak poważne konsekwencje. 6 . Podstawowe zasady alergologii molekularnej są przydatne zarówno dla pielęgniarek jak dietetyczek.

\section{Bibliografia/Bibliography:}

1. Chen JL, Bahna SL. Spice allergy. Journal. Ann Allergy Asthma Immunol 2011; 107(3):191-19.

2. Buczyłko K. Molekuły alergenowe. Wydawnictwo Alergologiczne Zdrowie Warszawa 2019.

3. Gawęcki J. Żywienie człowieka 1 Podstawy nauki o żywieniu. Wydawnictwo Naukowe PWN, Warszawa, 3, 2017.

4. Carlson G, Coop C. Pollen food allergy syndrome (PFAS): A review of current available literature. Ann Allergy Asthma Immunol. 2019, 123(4):359-365. 
5. Reese I, Ballmer-Weber B, Beyer K et al. German guideline for the management of adverse reactions to ingested histamine. Allergo J Int. 2017;26(2):72-79.

6. Ho MH, Wong WH, Chang C. Clinical spectrum of food allergies: a comprehensive review. Clin Rev Allergy Immunol 2014; 46(3):225-240.

7. Comas-Basté 0 , Sánchez-Pérez S, Veciana-Nogués MT, Latorre-Moratalla M, Vidal-Carou MDC. Histamine intolerance: the current state of art. Biomolecules. 2020; 10 (8): 1181-7.

8. Wagner A, Szwed A, Buczyłko K, Wagner W. Allergy to apple cultivars among patients with birch pollinosis and oral allergy syndrome. Ann Allergy Asthma Immunol. 2016;117(4):399-404.

9. Walter A, Seegräber M, Wollenberg A. Food-Related Contact Dermatitis, Contact Urticaria, and Atopy Patch Test with Food. Clin Rev Allergy Immunol. 2019,56 (1):19-31.

10. Wollenberg A, Vogel S. Patch testing for noncontact dermatitis: the atopy patch test for food and inhalants. Curr Allergy Asthma Rep. 2013;13(5):539-44.

11. Cingi C, Demirbas D, Songu M. Allergic rhinitis caused by food allergies. Eur Arch Otorhinolaryngol. 2010; 267(9):1327-35.

12. Takemura Y, Takaoka Y, Arima T et al. Association between fruit and vegetable allergies and pollen-food allergy syndrome in Japanese children: a multicenter cross-sectional case series. Asia Pac Allergy. 2020 Jan 31;10(1): e9. doi: 10.5415/apallergy. 2020.10. e9.

13. Mari A, Ballmer-Weber BK, Vieths S. The oral allergy syndrome: improved diagnostic and treatment methods. Curr Opin Allergy Clin Immunol. 2005,5:267-273. 
14. Śpiewak R. Praktyka wykonywania testów płatkowych w świetle aktualnych wytycznych. Wiadomości dermatologiczne, 3/2019 (14)56-66.

15. Muluk NB, Cingi C. Oral allergy syndrome. Am J Rhinol Allergy. 2018, 1;32(1):27-30.

16. Mastrorilli C, Tripodi S, Caffarelli C et al. Italian Pediatric Allergy Network (I-PAN). Endotypes of pollen-food syndrome in children with seasonal allergic rhinoconjunctivitis: a molecular classification. Allergy. 2016;71(8):1181-91.

17. Słowianek M, Skorupa M, Hallmann E, Rembiałkowska E, Leszczyńska J. Allergenic Potential of Tomatoes Cultivated in Organic and Conventional Systems. Plant Foods Hum Nutr. 2016;71(1):35-41.

18. Wagner A, Zielińska-Bliźniewska H, Wagner W. The Incidence of Delayed-Type Hypersensitivity Reactions to Apples Among Patients Allergic to Birch Pollen. Allergy Asthma Immunol Res. 2018;10(4):420-424.

19. Słowianek M, Leszczyńska J. Alergeny przypraw. Żywność. Nauka. Technologia. Jakość, 2011, 3 (76):15-28.

20. Warshaw EM, Schlarbaum JP, Maibach HI et al. Facial Dermatitis in Male Patients Referred for Patch Testing: Retrospective Analysis of North American Contact Dermatitis Group Data, 1994 to 2016. JAMA Dermatol. 2020,1;156(1):79-84.

21. Sharma AD. Relationship between nickel allergy and diet. Indian J Dermatol Venereol Leprol. 2007;73(5):307-12.

22. Aquino M, Rosner G. Systemic Contact Dermatitis. Clin Rev Allergy Immunol. 2019; 56(1):9-18.

23. Sharma AD. Low chromate diet in dermatology. Indian J Dermatol. 2009;54(3):293-5. 
24. Flavors and fragrances - ChemicalBook www.chemicalbook.com

25. Rozporządzenie Komisji (UE) 2017/1410.

26. Albanesi M, Pasculi C, Giliberti L et al. Immunological characterization of onion (Allium cepa) allergy. Postępy Dermatologii i Alergologii 1/2019,98-103. 